\title{
MAXILLARIA AUREOGLOBULA (ORCHIDACEAE, MAXILLARIINAE): A NEW RECORD FROM BRAZIL
}

\author{
Mathias E. Engels ${ }^{1,3} \&$ Lilien C. Ferneda Rocha ${ }^{2}$ \\ ${ }^{1}$ Assessoria Técnica Ambiental Ltda., Rua Marechal José Bernardino Bormann, 821, Batel, \\ Curitiba, Paraná, 80730-350 \\ 2 Juris Ambientis Consultores S S Ltda., Rua Humberto Costa, 96, Hugo Lange, \\ Curitiba, Paraná, 80040-150 \\ ${ }_{3}^{3}$ Author for correspondence: mathiasengels@hotmail.com
}

\begin{abstract}
AвSTRACt. We present the first record of Maxillaria aureoglobula from Brazil, found at Mato Grosso State, in Southern Amazon. A description, illustration, photos and comments about the species are provided.

Resumo. Apresentamos o primeiro registro de Maxillaria aureoglobula para o Brasil, encontrado no estado do Mato Grosso, na Amazônia meridional. É apresentada a descrição, ilustração, prancha fotográfica e comentários da espécie estudada.
\end{abstract}

Key words / Palavras chave: Brazil, Maxillariinae, Mormolyca, Neotropics, Teles Pires river / Brasil, Maxillariinae, Mormolyca, neotrópico, rio Teles Pires

Introduction. Maxillaria s.l. is one of the largest groups of Orchidaceae, it was segregated in many genera such as Mormolyca Fenzel proposed by Blanco et al. (2007). Recently Schuiteman \& Chase (2015) reestablished Maxillaria Ruiz \& Pav. in a broader genus, thereby Mormolyca is now treated as the section Rufescens Christenson.

The Maxillaria sect. Rufescens encompasses about 30 species (Arévalo et al. 2015, Schuiteman \& Chase 2015) distributed from south México to south Brazil (Carnevali \& Atwood 1996). Among the Maxillariinae it is characterized by pseudobulbs minutely verrucose, unifoliate, non-foliaceous sheaths; the inflorescences arising from the axils of rhizome bracts behind the younger pseudobulb; perianth open and without fibers, clavate and arcuate column, column foot very short, tomentose and insect-like labellum or callus with a pad of short trichomes, and apical dehiscence of capsules (Blanco et al. 2007, Arévalos et al. 2015).

There are only three species from the Maxillaria sect. Rufescens known from Brazil until now: Maxillaria calimaniana V.P. Castro; Maxillaria cleistogama Brieger \& Illg and Maxillaria rufescens Lindl. (BFG 2015; Schuitemann \& Chase, 2015), for more information about these species see Chiron \&
Bolsanello (2014) and BFG (2015). This new record for Brazil of Maxillaria aureoglobula Christenson was collected during the Flora Rescue of the Hydroeletric Power Plant of Colider, in Teles Pires River.

\section{TAXONOMIC TREATMENT}

Maxillaria aureoglobula Christenson, Orchids (West Palm Beach) 71: 125 (2002). इ Mormolyca aureoglobula (Christenson) M.A.Blanco, Lankesteriana 7: 531 (2007). EXanthoxerampellia aureoglobula (Christenson) Szlach. \& Sitko, Biodiversity Research and Conservation 25: 37 (2012). FIG. 1-2.

Epiphytic herbs, caespitose. Roots ca. $1 \mathrm{~mm}$ in diameter, terete, white brownish. Rhizomes ca. $3 \mathrm{~mm}$ in diameter, terete, $1.0-1.5 \mathrm{~cm}$ between pseudobulbs. Pseudobulbs $4.0-5.5 \times 1.1-2.0 \mathrm{~cm}$, ellipsoid, laterally flattened, flat (young) to minutely verrucose, heteroblastics, apically unifoliolate, green. Leaves $14.0-23.1 \times 1.9-2.6 \mathrm{~cm}$, narrowly lanceolate to oblong, conduplicate, subcoriaceous, discolor, green. Inflorescence 1-flowered, erect, produced from the rhizome between the pseudobulbs; peduncle $2.5-3.1 \times 0.1 \mathrm{~cm}$, terete, pale green; peduncle bracts 


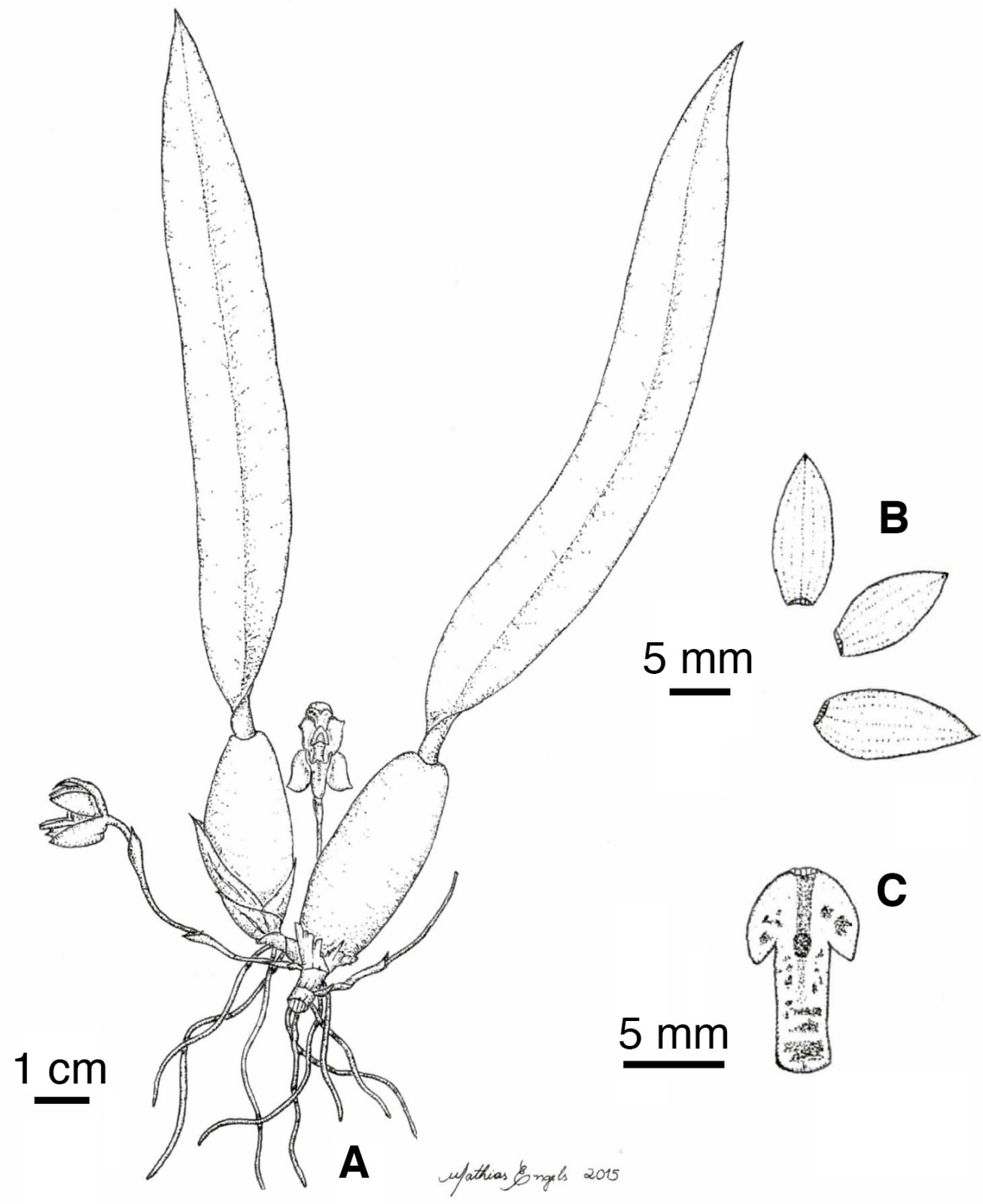

FiguRE 1. Maxillaria aureoglobula: A. Habit. B. Perianth flattened. C. Lip flattened (Engels 3085, TANG). Illustration by M.E.Engels.

$0.5-1.0 \times 0.3-0.6 \mathrm{~cm}$, oblanceolate, acute to obtuse, pale green to brown; floral bract ca. $1.2 \times 0.6 \mathrm{~cm}$, oblanceolate, acute, bright green to brownish. Flowers resupinate; ovary and pedicel ca. $1.3 \times 0.1 \mathrm{~cm}$, terete, 3 -sulcate, green; dorsal sepal ca. $1.2 \times 0.5 \mathrm{~cm}$, ellipticlanceolate, obtuse, yellow; lateral sepals ca. $1.3 \times 0.5$ $\mathrm{cm}$, lanceolate, acute-obtuse, yellow; petals ca. 1.1 $\times 0.4 \mathrm{~cm}$, elliptic-lanceolate, acute-obtuse, yellow; lip ca. $1.0 \times 0.6 \mathrm{~cm}$, trilobate, yellow with red spots; lateral lobes ca. $5.0 \times 1.5 \mathrm{~mm}$, eliptical, acute; central lobe ca. $6.0 \times 3.0 \mathrm{~mm}$, oblong, subtruncate; callus 2.0 $\times 1.0 \mathrm{~mm}$, elliptic-oblong, red, a little less than half 


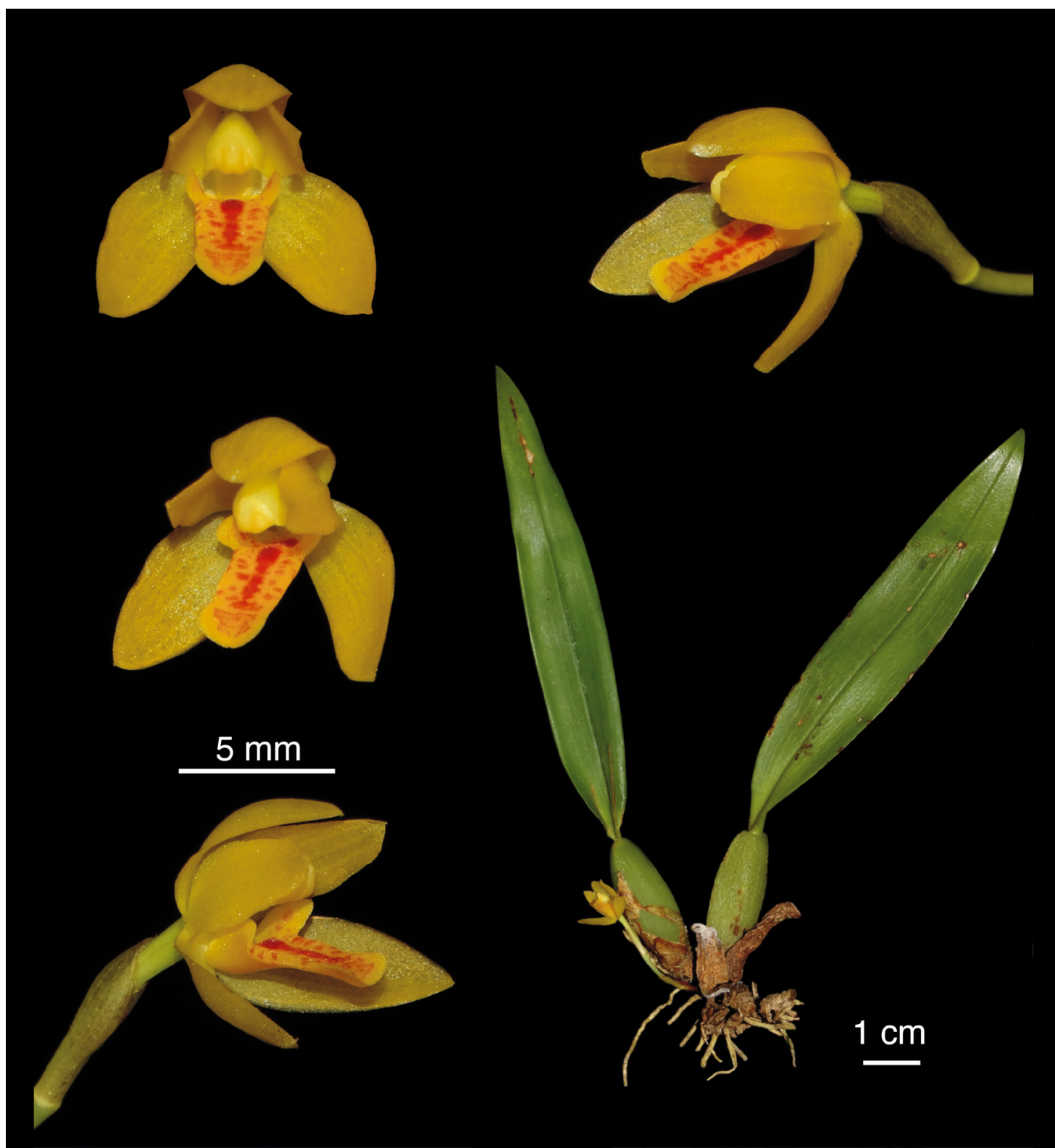

FIGURE 2. Maxillara aureoglobula: pictures showing habit and flowers (Engels 3085, TANG). Photos by M.E.Engels.

the length; column ca. $8.0 \times 2.0 \mathrm{~mm}$, subtriangular, arcuate, yellow. Anther ca. $2.0 \mathrm{~mm}$, globose, yellow. Fruit immature $3.6-4.0 \times 0.5-0.7 \mathrm{~cm}$, elliptic, green.

ExAmINED MATERIAL. BRAZIL. Mato Grosso: Itaúba, FLORA rescue from UHE Colíder, 2 September 2014, M.E. Engels 3300 (HERBAM, MBM); 16 April 2015, M.E. Engels 3085 (TANG - spirit collection).
Maxillaria aureoglobula occurs in Colombia, Venezuela (Schuiteman \& Chase 2015, Govaerts 2015) and Brazil, where it was found at Mato Grosso state as epiphyte in forests at margins of Teles Pires River in Southern Amazon.

These species is distinguished from other species that occur in Brazil by the globose flowers, entirely yellow or with reddish spots at lip, dorsal sepals and 
petals elliptic-lanceolate, laterals sepals lanceolate and lip with central lobe oblong. Maxillaria acutifolia Lindl. is it the closest species according to Christenson (2002). Maxillaria aureoglobula differs because of the flowers yellow with dorsal sepal elliptic-lanceolate and lateral sepals lanceolate while in M. acutifolia the flowers are brown or brown-yellowish with dorsal and lateral sepals elliptic. It flowered in April.

Acknowledgments. We thank to Companhia Paranaense de Energia (COPEL) for allow and encourage the publication of the data of this work. To Consórcio CIA Ambiental and staff. To Antonio L.V. Toscano de Brito; Fernanda M.C. de Oliveira; Marcos Klingelfus; Thuane Bochorny de Souza Braga and Vitorino P. Castro Neto for the help with the bibliography.

\section{LiTERATURE CITED}

Arévalo, R.; Carnevali, G. \& Cameron, K.M. (2015). Three New Species of Mormolyca (Orchidaceae: Maxillariinae) with an Updated Molecular Phylogenetic Analysis. Systematic Botany, 40(3), 692-705.
BFG - The Brazil Flora Group (2015). Growing knowledge: an overview of seed plants diversity in Brazil. Rodriguésia, 66(4), 1085-1113.

Blanco, M. A., Carnevali, G., Whitter, W. M., Singer, R. B., Koehler, S., Williams, N. H., Ojeda, I., Neubig, K.M. \& Endara, L. (2007). Generic realignments in Maxillariinae (Orchidaceae). Lankesteriana, 7(3), 515537.

Carnevali, G. \& Atwood, J. (1996). Two new species in the Maxillaria rufescens complex from Central América. Lindleyana, 11(1), 27-33.

Chiron, G. \& Bolsanello, R. X. (2014). Orchidées du Brésil - As orquídeas da Serra do Castelo (Espírito Santo Brasil). 1 ed., v.4, Tropicalia, Voreppe, France.

Christenson, E. A. (2002). New Colombian orchids: descriptions of species from an orchids show. Orchids, Magazine of the American Orchid Society, 71(2), 124129.

Govaerts, R. (2015). World Checklist of Selected Plant Families. Facilitated by the Royal Botanic Gardens, Kew. www.kew.org/wcsp/monocots (accessed 2015 April 22).

Schuiteman, A. \& Chase, M. (2015). A reappraisal of Maxillaria (Orchidaceae). Phytotaxa,225(1), 1-78. 